\title{
Respon Seleksi Indeks Dasar pada Tanaman Jagung (Zea mays L.) di Lahan Kering
}

\section{Response of Basic Index Selection for Corn (Zea mays L.) on Dry Land}

\author{
I Wayan Sudika*1, I Nyoman Soemeinaboedhy ${ }^{2}$ \\ ${ }^{1}$ Program Studi Agroekoteknologi Fakultas Pertanian Universitas Mataram, Indonesia \\ ${ }^{2}$ Program studi Ilmu Tanah Fakultas Pertanian Universitas Mataram, Indonesia \\ *corresponding author, email: sudikawayanms@gmail.com
}

Manuscript received: 28-09-2020. Accepted: 12-10-2020

\begin{abstract}
ABSTRAK
Penelitian ini bertujuan untuk mengetahui respon seleksi, rata-rata hasil dan bobot brangkasan segar pada tanaman jagung hasil seleksi massa dengan teknik indeks dasar hingga delapan siklus dan mengkaji parameter genetik sifat-sifat kuantitatif. Rancangan Acak Kelompok, digunakan untuk pengujian hasil seleksi dengan jumlah perlakuan 11 populasi. Setiap perlakuan diulang 3 kali, sehingga diperoleh 33 unit percobaan. Data hasil percobaan dianalisa dengan analisis sidik ragam pada taraf nyata 5 persen. Rata-rata perlakuan diuji lanjut dengan uji $\mathrm{BNT}_{0,05}$. Respon seleksi diperoleh dari koefisien regresi linier sederhana antar sifat yang diamati dengan siklus seleksi. Hasil penelitian menunjukkan, bahwa hasil dan bobot brangkasan segar memiliki respon seleksi massa dengan teknik indeks dasar per siklus berturut-turut sebesar $0.230 \mathrm{~kg} \mathrm{plot}^{-1}(3.39 \%)$ dan $10.633 \mathrm{~g}$ $\tan ^{-1}(4.21 \%)$.; keduanya tergolong sedang. Rata-rata hasil populasi siklus kedelapan lebih tinggi dibanding dengan populasi awal dan varietas Gumarang; namun sama dengan varietas Lamuru. Bobot brangkasan segar antar perlakuan sama. Hasil populasi awal, populasi siklus kedelapan, varietas Gumarang dan Lamuru berturut-turut sebesar $5.653 \mathrm{t} \mathrm{ha}^{-1} ; 8.035 \mathrm{tha}^{-1} ; 5.278 \mathrm{t} \mathrm{ha}^{-1}$ dan 7.410 $\mathrm{t} \mathrm{ha}^{-1}$. Peningkatan sifat tinggi tanaman, jumlah daun total per tanaman, jumlah daun segar saat panen dan seluruh komponen hasil, menyebabkan peningkatkan daya hasil. Peningkatan bobot brangkasan segar terjadi apabila ada peningkatan tinggi tanaman, jumlah daun total, diameter batang dan jumlah daun segar saat panen. Sifat yang pengaruh genetiknya lebih besar dibanding pengaruh lingkungan, yaitu bobot tongkol kering panen, panjang tongkol dan hasil.
\end{abstract}

Kata kunci : hasil; genetik; lamuru; massa; seleksi

\begin{abstract}
This research aimed to identificate the selection response, the avarage of yield and fresh stover weight of corn during eight cycles of mass selection with basic index technique and observe the genetic parameter of quantitative characteristics. The randomized block design was used to test the selected with 11 treatment populations. Each treatment was replicated 3 times, in order to obtain 33 experimental units. The experimental data were analyzed with analysis of variance at $5 \%$ levels. The average treatment was tested by the $\mathrm{LSD}_{0.05}$. The selection response was obtained from the simple
\end{abstract}


linear regression coefficient between the observed traits with selection cycles. The result of this research, shows the yield and fresh stover weight has a response mass selection with basic index technique per cycle at $0.230 \mathrm{~kg} \mathrm{plot}^{-1}(3.39 \%)$ and $10.633 \mathrm{~g} \mathrm{tan}^{-1}(4.21 \%)$, respectively; both of them moderate catagories. The average of yield of eighth cycle population was higher compare to initial population and Gumarang; but the same with Lamuru variety. The weight of fresh stover was the same between treatments. The yield of initial population, eighth cycle population, Gumarang and Lamuru varieties were $5.653 \mathrm{tha}^{-1} ; 8.035 \mathrm{t} \mathrm{ha}^{-1} ; 5.278 \mathrm{t} \mathrm{ha}^{-1}$ and $7.410 \mathrm{t} \mathrm{ha}^{-1}$, respectively. The increased of plant height, total number of leaves per plant, number of fresh leaves at harvest and all yield components, were increased the yield. The increased of fresh stover weight occured when there were increased in plant height, total number of leaves, stem diameter and number of fresh leaves at harvest. The characteristic with the higher genetic effect than the environment effect found in weight of ear harvest, length of ear and yield.

Keywords: genetic; lamuru; mass; selection; yield

\section{PENDAHULUAN}

Indonesia mempunyai lahan kering yang cukup luas dan seiring dengan peningkatan jumlah penduduk, maka lahan kering dijadikan lahan yang produktif untuk pertanian. Salah satu komoditas yang cocok untuk dibudidayakan di lahan kering adalah tanaman jagung (Wedastara, 2011). Lahan kering umumnya memiliki produktivitasnya yang rendah akibat ketergantungannya pada curah hujan (Budiyanto, 2014). Helmiyanti et al. (2012) menambahkan, bahwa masalah pertanian lahan kering, yaitu adanya keterbatasan air, produktivitas lahan rendah dan sebagian besar petaninya subsistem serta belum banyak yang memahami tentang manfaat kotoran ternak sebagai pensuplai unsur hara. Oleh karena itu, diperlukan varietas yang sesuai untuk lahan kering. Menurut Sudika et al (2018a), bahwa varietas jagung yang lebih tahan terhadap cekaman kekeringan, yaitu umur genjah $(<.90$ hari) dan berupa varietas komposit. Pembentukan varietas komposit dapat dilakukan dengan seleksi; salah satunya adalah seleksi massa.

Seleksi massa dengan teknik indeks dasar, telah dilakukan hingga siklus kedelapan dengan menggunakan populasi awal hasil rakitan kultivar lokal (PHRKL) oleh Sudika et al, 2019). Seleksi diarahkan untuk perbaikan daya hasil dan brangkasan segar. Daya hasil secara tidak langsung diperbaiki melalui bobot tongkol kering panen; sedangkan brangkasan segar dilakukan secara langsung. Seleksi secara tidak langsung dapat dilakukan apabila sifat yang diperbaiki dengan sifat yang diseleksi berkorelasi positif (Faiqon et al., 2017). Perbaikan genetik suatu populasi akan berhasil apabila dalam populasi tersebut terdapat variabilitas (keragaman) genetik yang tinggi (Andriani et al., 2015). Keragaman genetik dapat diartikan sebagai variasi gen dan genotip antar dan dalam individu. (Pabendon, 2010).

Keberhasilan pelaksanaan seleksi dapat ditentukan dari besarnya nilai respon seleksi. Hasil penelitian Sudika et al. (2018a), bahwa respon seleksi hingga siklus ketujuh sebesar 4,5\% pada sifat bobot biji kering pipil (daya hasil). Namun, capaian daya hasil dari populasi siklus ketujuh yakni sebesar $6.46 \mathrm{t} \mathrm{ha}^{-1}$ tidak berbeda jika dibandingkan dengan daya hasil varietas unggul Gumarang yakni sebesar $5.67 \mathrm{t} \mathrm{ha}^{-1}$. Oleh karena itu, seleksi massa dengan indeks dasar dilanjutkan pada siklus kedelapan; namun belum diketahui kemajuan seleksinya. . Tujuan penelitian adalah mengetahui rata-rata respon seleksi massa dengan indeks dasar per siklus hingga delapan siklus dan mengetahui rata-rata daya hasil dan bobot 
brangkasan segar populasi siklus kedelapan dibanding populasi awal, varietas unggul Gumarang dan Lamuru.

\section{BAHAN DAN METODE}

\section{Bahan}

Benih yang digunakan dalam percobaan ini, yaitu benih jagung varietas Gumarang, Lamuru, populasi awal, populasi hasil seleksi siklus pertama hingga siklus kedelapan. Pupuk yang digunakan meliputi pupuk Petroganik, pupuk Urea, pupuk NPK Phonska (15-15-15); sedangkan pestisidanya, yaitu Furadan 3G, Saromyl 35 SD, Calaris 550 SC, Alika 247 ZC dan Prevaton 50 SC.

\section{Metode Penelitian dan Rancangan Percobaan}

Metode yang digunakan dalam penelitian ini adalah metode eksperimental dengan percobaan di lahan kering. Percobaan telah dilakukan di dusun Luwuk, desa Tempos, kecamatan Gerung, kabupaten Lombok Barat, mulai bulan Maret sampai dengan bulan Juni 2019. Rancangan percobaan yang digunakan adalah Rancangan Acak Kelompok dengan 11 perlakuan, yaitu populasi awal (P0), populasi hasil seleksi siklus pertama hingga siklus kedelapan (P1IS hingga P8IS), varietas unggul Gumarang dan Lamuru. Setiap perlakuan diulang 3 kali, sehingga diperoleh 33 unit percobaan. Karaktristik lahan, yaitu tekstur tanah geluh dan jenis tanah inseptisol. Tingkat keasaman ( $\mathrm{pH}$ ) tanah 6.43 (agak asam), nitrogen total 0.04 dengan kriteria sangat rendah, fospor tersedia dan kalium tertukar secara berturut-turut $24.18 \mathrm{ppm}$, 1.97 ppm; masuk kriteria sangat tinggi

Pelaksanaan

Seluruh benih terlebih dahulu diperlakukan dengan Saromyl 35 SD dengan dosis $5 \mathrm{~g}$ $\mathrm{kg}^{-1}$ sebelum tanam guna mencegah penyakit bulai (Seclerospora maydis). Tanah petak pengujian terlebih dahulu diolah dengan cara dibajak dan digaru masing-masing satu kali. Selanjutnya tanah diratakan dengan cangkul. Petak pengujian dibagi 3 blok, masing-masing blok terdapat 11 plot. Ukuran setiap plot adalah 3 x $4 \mathrm{~m}$. Setiap plot memuat satu perlakuan; yang terdiri atas lima baris, masing-masing baris 20 tanaman, sehingga seluruhnya maksimal terdapat 100 tanaman. Jarak tanam yang digunakan adalah $20 \times 60 \mathrm{~cm}$, satu tanaman per lubang.

Pupuk NPK Phonska (15-15-15) dan pupuk Urea dengan dosis berturut-turut $300 \mathrm{~kg}$ $\mathrm{ha}^{-1}$ dan $200 \mathrm{~kg} \mathrm{ha}^{-1}$. Pupuk diberikan sebanyak dua kali; masing-masing setengah dosis, yaitu saat tanam dan pada umur 28 hari sejak tanam. Cara kedua pemupukan, dilakukan secara tugal. Pemupukan pertama dengan membuat lubang di samping kanan lubang tanam dan yang kedua di antara tanaman dalam barisan.

Benih yang tidak tumbuh, diganti menggunakan tanaman cadangan yang ditempatkan di antara barisan dalam setiap plot pada umur 12 hari setelah tanam. Tanaman yang tumbuh lebih dari satu setiap lubang, dicabut pada umur 14 hari.

Penyiangan dilakukan pada umur 16 hari setelah tanam dengan menyemprotkan herbisida Calaris 550 SC. Pembumbunan dilakukan dengan mencangkul tanah di antara barisan tanaman, kemudian ditimbunkan ke kiri dan ke kanan. Kegiatan ini dilakukan pada umur 28 hari setelah tanam. Pengairan tidak dilakukan selama percobaan karena pertanaman 
memperoleh air dari adanya hujan. Pertanaman diserang oleh hama penggerek bunga jantan mulai umur 40 hari. Pengendaliannya dilakukan menyemprotkan larutan Prevaton 50 SC dicampur dengan Alika 247 ZC. Dosis yang digunakan adalah 400 1.ha ${ }^{-1}$

Panen dilakukan setelah 85 persen tanaman dalam setiap plot memenuhi syarat kriteria panen. Kriteria panen yang digunakan yaitu kelobot dan rambut tongkol telah kering, biji keras dan mengkilat dan apabila dipijit tidak berbekas.

Peubah yang diamati meliputi tinggi tanaman, jumlah daun total, diameter batang, jumlah daun segar saat panen, bobot brangkasan segar per tanaman, panjang tongkol, diameter tongkol, bobot tongkol kering panen per tanaman, bobot biji kering pipil per plot (hasil) dan bobot 1000 biji.

Data hasil pengamatan dianalisa dengan analisis sidik ragam pada taraf nyata $5 \%$. Apabila antar perlakuan beda nyata, maka dilanjutkan dengan uji BNT 0.05 . Respon seleksi per siklus, diperoleh dari koefisien regresi linear sederhana antara sifat yang diamati dengan siklus seleksi yang dijabarkan dari persamaan linear (Liitle dan Hills, 1972), sebagai berikut:

$$
\widehat{Y}_{L}=\bar{Y}+\left(K_{2} P_{1}\right) X^{\prime}
$$

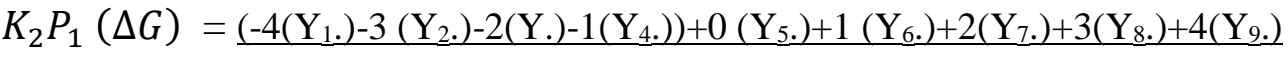

$(-4)^{2}+(-3)^{2}+(-2)^{2}+(-1)^{2}+(0)^{2}+(1)^{2}+(2)^{2}+(3)^{2}+(4)^{2} \times$ r

dengan

$K_{2} P_{1}(\Delta G)$ adalah koefisien regresi linier dan digunakan untuk menyatakan rata-rata respon seleksi per siklus. $Y_{1}, Y_{2}$. hingga $Y_{9}$, berturut-turut merupakan total P0, P1IS hingga P8IS. Apabila koefisien regresi linier bersifat nyata; berarti memiliki (ada) respon seleksi; sebaliknya tidak memiliki (tidak ada) respon seleksi, apabila koefisien regresi bersifat tidak nyata. Respon seleksi per siklus, selanjutnya dinyatakan dalam persen menggunakan rumus:

$\left(\mathrm{K}_{2} \mathrm{P}_{1} / \mathrm{P} 0\right) \times 100 \%$

dengan P0, merupakan rata-rata populasi awal. Selanjutnya dilakukan penggolongan menurut Karmana, et al. (1990), yaitu rendah (0 - <3.3\%); sedang (3.3 - <6.6\%); cukup tinggi $(6.6-<10.0 \%)$ dan tinggi $(>10 \%)$.

Heritabilitas arti luas $\left(\mathrm{H}^{2}\right)$ diperoleh dengan rumus (Ujianto et al., 2020) :

$$
\mathrm{H}^{2}=\frac{\sigma^{2} G}{\sigma^{2} P} \times 100 \%
$$

Nilai heritabilitas yang diperoleh selanjutnya digolongkan sesuai pendapat Syukur et al. (2012), yaitu katagori tinggi, > $50.00 \%$; sedang, 20.00 - $50.00 \%$ dan katagori rendah apabila $<20.00 \%$.

Koefisien Keragaman genetik dapat diperoleh dari rumus (Ujianto et al., 2020):

$$
\mathrm{KKG}=\frac{\sqrt{\sigma^{2} \mathrm{G}}}{\bar{x}} \times 100 \% .
$$

Penggolongan selanjutnya untuk nilai KKG mengikuti katagori yang dibuat oleh Milligan et al. dalam Istianingrum \& Damanhuri (2016), yaitu katagori rendah dengan nilai KKG < 5\%; sedang, 5-14.5\% dan katagori tinggi apabila nilai KKG $>14.5 \%$.

Nilai koefisien korelasi dapat diperoleh dari rumus (Sofyan, 2011):

$$
r=\frac{\operatorname{Cov}_{12}}{\sqrt{\sigma^{2} G_{1} \times \sigma^{2} G_{2}}}
$$


Penggolongan nilai koefisien korelasi mengikuti Guilford dalam Somantri dan Muhidin (2006), yaitu $0,00<\mathrm{r}<0.20 /-0.20<\mathrm{r} \leq 0.00$ tergolong sangat lemah; $0.20 \leq \mathrm{r}<0.40 /-0.40$ $<\mathrm{r} \leq-0.20$ (lemah); $0.40 \leq \mathrm{r}<0.70 /-0.70<\mathrm{r} \leq-0.40$ (sedang); $0.70 \leq \mathrm{r}<0.90 /-0.90<\mathrm{r} \leq-$ 0.70 (kuat) dan tergolong sangat kuat apabila nilainya $0.90 \leq \mathrm{r}<1,00 /-1.00<\mathrm{r} \leq-0.90$.

\section{HASIL DAN PEMBAHASAN}

\section{Hasil}

Seleksi massa dengan teknik indeks dasar telah dilakukan selama delapan siklus. Perbaikan diarahkan untuk meningkatkan hasil dan brangkasan segar, melalui sifat bobot tongkol kering panen dan bobot bangkasan segar. Bobot kedua sifat tersebut, diperoleh dari nilai ekonomis masing-masing. Populasi hasil seleksi telah diuji dan rata-rata respon seleksi per siklus hingga delapan siklus seleksi massa dengan indeks dasar, disajikan pada Tabel 1. Heritabilitas arti luas dan koefisien keragaman genetic disajikan pada Tabel 2. Rata-rata hasil dan brangkasan segar serta sifat-sifat lain, disajikan pada Tabel 3 dan Tabel 4; sedangkan nilai koefisien korelasi antar sifat dengan hasil dan dengan brangkasan segar disajikan pada Tabel 5.

Tabel 1. Rata-rata respon seleksi per siklus untuk seluruh sifat yang diamati

\begin{tabular}{|c|c|c|c|c|}
\hline No & Sifat yang diamati & $\begin{array}{l}\text { Respon } \\
\text { seleksi per } \\
\text { siklus }\end{array}$ & $\begin{array}{l}\text { Persentase } \\
\text { respon } \\
\text { seleksi per } \\
\text { siklus }(\%)\end{array}$ & Katagori \\
\hline 1 & Tinggi tanaman $(\mathrm{cm})$ & $1.999 \mathrm{~s}$ & 1.12 & Rendah \\
\hline 2 & Jumlah daun total per tanaman (helai) & $0.143 \mathrm{~s}$ & 1.30 & Rendah \\
\hline 3 & Diameter batang $(\mathrm{mm})$ & $0.179 \mathrm{~ns}$ & 0.99 & Rendah \\
\hline 4 & Jumlah daun segar saat panen (helai) & $0.215 \mathrm{~s}$ & 3.71 & Sedang \\
\hline 5 & Bobot brangkasan segar per tanaman (g) & $10.633 \mathrm{~s}$ & 4.21 & Sedang \\
\hline 6 & $\begin{array}{l}\text { Bobot tongkol kering panen per tanaman } \\
(\mathrm{g})\end{array}$ & $2.794 \mathrm{~s}$ & 2.21 & Rendah \\
\hline 7 & Panjang Tongkol (cm) & $0.110 \mathrm{~s}$ & 0.87 & Rendah \\
\hline 8 & Diameter Tongkol (cm) & $0.039 \mathrm{~s}$ & 0.94 & Rendah \\
\hline 9 & Bobot 1.000 butir biji (g) & $3.653 \mathrm{~s}$ & 1.59 & Rendah \\
\hline 10 & Hasil (bobot biji kering pipil per plot) $(\mathrm{kg})$ & $0.230 \mathrm{~s}$ & 3.39 & Sedang \\
\hline
\end{tabular}

Keterangan: s, memiliki (ada) respon seleksi ns, tidak memliki (tidak ada) respon seleksi.

Pada Tabel 1 terlihat, bahwa tidak ada respon seleksi per siklus untuk diameter batang; sedangkan sifat-sifat lain memiliki respon seleksi. Respon seleksi per siklus hasil sebesar $0.230 \mathrm{~kg} \mathrm{plot}^{-1}$ (3.39\%) dan bobot brangkasan segar, sebesar $10.633 \mathrm{~g} \mathrm{tan}^{-1}(4.21 \%)$; keduanya tergolong sedang. Jumlah daun segar saat panen, respon seleksnya tergolong sedang. Sifat-sifat lain termasuk bobot tongkol kering panen per tanaman memiliki respon tergolong rendah.

Pada Tabel 2 terlihat, bahwa heritabilitas arti luas tergolong tinggi diperoleh pada bobot tongkol kering panen per tanaman, panjang tongkol dan hasil. Sifat-sifat lainnya tergolong sedang; kecuali diameter batang memiliki heritabilitas tergolong rendah. Jjumlah daun segar saat panen per tanaman, bobot brangkasan segar per tanaman, bobot tongkol 
kering panen per tanaman dan hasil memiliki nilai koefisien keragaman genetik (KKG) tergolong sedang; sedangkan sifat-sifat lain tergolong rendah.

Tabel 2. Nilai heritabilitas arti luas $\left(\mathrm{H}^{2}\right)$ dan nilai koefisien keragaman genetic (KKG) seluruh sifat yang diamati

\begin{tabular}{|c|c|c|c|c|c|}
\hline No. & Sifat-sifat yang diamati & $\begin{array}{l}\text { Nilai H }^{2} \\
(\%)\end{array}$ & Katagori & $\begin{array}{c}\text { Nilai KKG } \\
(\%)\end{array}$ & Katagori \\
\hline 1 & Tinggi tanaman & 44.29 & Sedang & 4.94 & Rendah \\
\hline 2 & Jumlah daun total per tanaman & 43.27 & Sedang & 4.61 & Rendah \\
\hline 3 & Diameter batang & 10.79 & Rendah & 2.64 & Rendah \\
\hline 4 & $\begin{array}{l}\text { Jumlah daun segar saat panen } \\
\text { per tanaman }\end{array}$ & 41.03 & Sedang & 8.75 & Sedang \\
\hline 5 & $\begin{array}{l}\text { Bobot brangkasan segar per } \\
\text { tanaman }\end{array}$ & 26.61 & Sedang & 9.54 & Sedang \\
\hline 6 & $\begin{array}{l}\text { Bobot tongkol kering panen per } \\
\text { tanaman }\end{array}$ & 60.27 & Tinggi & 10.78 & Sedang \\
\hline 7 & Panjang tongkol & 60.10 & Tinggi & 4.02 & Rendah \\
\hline 8 & Diameter tongkol & 38.75 & Sedang & 2.97 & Rendah \\
\hline 9 & Bobot 1.000 butir biji & 36.11 & Sedang & 4.58 & Rendah \\
\hline 10 & $\begin{array}{l}\text { Hasil (bobot biji kering pipil per } \\
\text { plot) }\end{array}$ & 59.01 & Tinggi & 10.47 & Sedang \\
\hline
\end{tabular}

Tabel 3. Rata-rata variabel pertumbuhan tanaman jagung untuk setiap perlakuan

\begin{tabular}{llccccc}
\hline No. & Perlakuan & $\begin{array}{c}\text { Tinggi } \\
\text { tanaman } \\
(\mathrm{cm})\end{array}$ & $\begin{array}{c}\text { Jumlah } \\
\text { daun } \\
\text { (helai) }\end{array}$ & $\begin{array}{c}\text { Diameter } \\
\text { batang }(\mathrm{mm})\end{array}$ & $\begin{array}{c}\text { Jumlah daun } \\
\text { segar saat } \\
\text { panen } \\
\text { (helai) }\end{array}$ & $\begin{array}{c}\text { Bobot } \\
\text { brangkasan } \\
\text { segar per } \\
\text { tanaman }(\mathrm{g})\end{array}$ \\
\hline 1 & P8IS & $198.46 \mathrm{a}$ & $12.46 \mathrm{a}$ & 21.08 & $7.98 \mathrm{a}$ & 252.79 \\
2 & P0 & $178.17 \mathrm{~b}$ & $11.04 \mathrm{~b}$ & 18.00 & $5.79 \mathrm{~b}$ & 270.85 \\
3 & P1IS & $213.45 \mathrm{a}$ & $10.79 \mathrm{~b}$ & 19.67 & $5.50 \mathrm{~b}$ & 346.08 \\
4 & P2IS & $192.46 \mathrm{a}$ & $12.21 \mathrm{a}$ & 19.90 & $6.67 \mathrm{~b}$ & 362.19 \\
5 & P3IS & $209.73 \mathrm{a}$ & $11.51 \mathrm{a}$ & 19.71 & $6.78 \mathrm{a}$ & 395.89 \\
6 & P4IS & $203.84 \mathrm{a}$ & $12.42 \mathrm{a}$ & 18.79 & $7.04 \mathrm{a}$ & 383.96 \\
7 & P5IS & $209.35 \mathrm{a}$ & $12.13 \mathrm{a}$ & 20.79 & $6.75 \mathrm{a}$ & 316.20 \\
8 & P6IS & $213.24 \mathrm{a}$ & $11.92 \mathrm{a}$ & 18.50 & $6.92 \mathrm{a}$ & 341.83 \\
9 & P7IS & $212.65 \mathrm{a}$ & $11.75 \mathrm{a}$ & 19.71 & $6.75 \mathrm{a}$ & 368.55 \\
10 & Gumarang & $210.75 \mathrm{a}$ & $11.92 \mathrm{a}$ & 19.21 & $7.29 \mathrm{a}$ & 371.25 \\
11 & Lamuru & $210.75 \mathrm{a}$ & $13.13 \mathrm{a}$ & 18.21 & $7.67 \mathrm{a}$ & 341.84 \\
BNT $_{0,05}$ & 19.35 & 1.08 & - & 1.22 & - \\
\hline
\end{tabular}

Keterangan: Angka-angka yang diikuti huruf sama pada kolom sama, tidak berbeda nyata dengan uji $\mathrm{BNT}_{0,05}$

Pada Tabel 3 terlihat, bahwa tinggi tanaman, jumlah daun total dan jumlah daun segar saat panen populasi siklus ke delapan (P8IS) lebih tinggi dibanding dibanding populasi awal (P0); namun sama dengan varietas Gumarang dan Lamuru. Diameter batang dan bobot brangkasan antar perlakuan sama. 
Tabel 4. Rata-rata untuk variabel hasil dan komponen hasil setiap perlakuan

\begin{tabular}{llccccc}
\hline No. & Perlakuan & $\begin{array}{c}\text { Bobot tongkol } \\
\text { kering panen } \\
\left.(\mathrm{g} \mathrm{tan})^{-1}\right)\end{array}$ & $\begin{array}{c}\text { Panjang } \\
\text { tongkol } \\
(\mathrm{cm})\end{array}$ & $\begin{array}{c}\text { Diameter } \\
\text { tongkol } \\
(\mathrm{cm})\end{array}$ & $\begin{array}{c}\text { Bobot } 1.000 \\
\text { butir biji }(\mathrm{g})\end{array}$ & $\begin{array}{c}\text { Hasil (bobot biji } \\
\text { kering pipil) } \\
\left(\mathrm{kg} \mathrm{plot}^{-1}\right)\end{array}$ \\
\hline 1 & P8IS & $171.02 \mathrm{a}$ & $14.18 \mathrm{a}$ & $4.65 \mathrm{a}$ & $272.13 \mathrm{a}$ & $9.64 \mathrm{a}$ \\
2 & P0 & $126.72 \mathrm{~b}$ & $12.59 \mathrm{~b}$ & $4.15 \mathrm{~b}$ & $229.27 \mathrm{~b}$ & $6.78 \mathrm{~b}$ \\
3 & P1IS & $139.63 \mathrm{~b}$ & $13.33 \mathrm{~b}$ & $4.35 \mathrm{~b}$ & $236.70 \mathrm{~b}$ & $7.38 \mathrm{~b}$ \\
4 & P2IS & $149.82 \mathrm{a}$ & $13.27 \mathrm{~b}$ & $4.38 \mathrm{a}$ & $241.97 \mathrm{~b}$ & $7.60 \mathrm{~b}$ \\
5 & P3IS & $143.40 \mathrm{~b}$ & $13.23 \mathrm{~b}$ & $4.21 \mathrm{~b}$ & $244.70 \mathrm{~b}$ & $7.68 \mathrm{~b}$ \\
6 & P4IS & $149.28 \mathrm{a}$ & $13.32 \mathrm{~b}$ & $4.36 \mathrm{~b}$ & $241.10 \mathrm{~b}$ & $7.55 \mathrm{~b}$ \\
7 & P5IS & $158.98 \mathrm{a}$ & $13.35 \mathrm{~b}$ & $4.39 \mathrm{a}$ & $249.93 \mathrm{a}$ & $7.74 \mathrm{~b}$ \\
8 & P6IS & $134.58 \mathrm{~b}$ & $12.59 \mathrm{~b}$ & $4.34 \mathrm{~b}$ & $249.77 \mathrm{a}$ & $7.72 \mathrm{~b}$ \\
9 & P7IS & $141.43 \mathrm{~b}$ & $13.59 \mathrm{a}$ & $4.42 \mathrm{a}$ & $245.67 \mathrm{~b}$ & $8.07 \mathrm{~b}$ \\
10 & Gumarang & $127.63 \mathrm{~b}$ & $12.47 \mathrm{~b}$ & $4.19 \mathrm{~b}$ & $224.67 \mathrm{~b}$ & $6.33 \mathrm{~b}$ \\
11 & Lamuru & $183.46 \mathrm{a}$ & $14.86 \mathrm{a}$ & $4.63 \mathrm{a}$ & $266.83 \mathrm{a}$ & $8.89 \mathrm{a}$ \\
$\mathrm{BNT}_{0,05}$ & 22.07 & 0.75 & 0.28 & 25.51 & 1.16 \\
\hline
\end{tabular}

Keterangan: Angka-angka yang diikuti huruf sama pada kolom sama, tidak berbeda nyata dengan uji $\mathrm{BNT}_{0,05}$.

Pada Tabel 4 dapat dilhat, bahwa hasil (bobot biji kering pipil per plot) populasi P8IS lebih tinggi dibanding P0, varietas unggul Gumarang dan populasi hasil seleksi lainnya; namun sama dengan varietas unggul Lamuru. Hasil P8IS, P0, varietas Gumarang dan Lamuru, berturut-turut sebesar $9.64 \mathrm{~kg} \mathrm{plot}^{-1}$ (8.035 t ha-1); 6.78 (5.653); 6.33 (5.278) dan $8.89 \mathrm{~kg} \mathrm{plot}^{-1}\left(7.410 \mathrm{t} \mathrm{ha}^{-1}\right)$. Populasi P8IS memiliki bobot tongkol kering panen per tanaman dan bobot.1.000 butir biji lebih tinggi dibanding P0 dan Gumarang; namun sama dengan Lamuru. Ukuran tongkol (panjang tongkol dan diameter tongkol) P8IS lebih besar dibanding P0 dan Gumarang; tetapi sama dengan Lamuru.

Tabel 5. Nilai koefisien korelasi antar hasil dengan sifat-sifat lain yang diamati

\begin{tabular}{|c|c|c|c|c|c|}
\hline No. & $\begin{array}{c}\text { Sifat-sifat yang } \\
\text { diamati }\end{array}$ & $\begin{array}{c}\text { Nilai koefisien } \\
\text { korelasi } \\
\text { fenotipik } \\
\text { dengan hasil }\end{array}$ & Katagori & $\begin{array}{c}\text { Nilai koefisien } \\
\text { korelasi fenotipik } \\
\text { dengan bobot } \\
\text { brangkasan segar }\end{array}$ & Katagori \\
\hline 1 & Tinggi tanaman & $0.43 \mathrm{~s}$ & Sedang & $0.57 \mathrm{~s}$ & Sedang \\
\hline 2 & $\begin{array}{l}\text { Jumlah daun total per } \\
\text { tanaman }\end{array}$ & $0.45 \mathrm{~s}$ & Sedang & $0.62 \mathrm{~s}$ & Sedang \\
\hline 3 & Diameter batang & $0.21 \mathrm{~ns}$ & Lemah & $0.54 \mathrm{~s}$ & Sedang \\
\hline 4 & $\begin{array}{l}\text { Jumlah daun segar } \\
\text { saat panen per } \\
\text { tanaman }\end{array}$ & $0.38 \mathrm{~s}$ & Lemah & $0.51 \mathrm{~s}$ & Sedang \\
\hline 5 & $\begin{array}{l}\text { Bobot brangkasan } \\
\text { segar per tanaman }\end{array}$ & $0.26 \mathrm{~ns}$ & Lemah & $1.00 \mathrm{~s}$ & Sangat kuat \\
\hline 6 & $\begin{array}{l}\text { Bobot tongkol kering } \\
\text { panen per tanaman }\end{array}$ & $0.74 \mathrm{~s}$ & Kuat & $0.33 \mathrm{~ns}$ & Lemah \\
\hline 7 & Panjang tongkol & $0.70 \mathrm{~s}$ & kuat & $0.23 \mathrm{~ns}$ & Lemah \\
\hline 8 & Diameter tongkol & $0.77 \mathrm{~s}$ & Kuat & $0.19 \mathrm{~ns}$ & $\begin{array}{l}\text { Sangat } \\
\text { lemah }\end{array}$ \\
\hline 9 & Bobot 1.000 butir biji & $0.76 \mathrm{~s}$ & Kuat & $0.29 \mathrm{~ns}$ & Lemah \\
\hline
\end{tabular}

Keterangan: s, berkorelasi nyata pada taraf $5 \%$ dan ns, berkorelasi tidak nyata. 
Tabel 5 menunjukkan, bahwa tinggi tanaman, jumlah daun total per tanaman, jumlah daun segar saat panen per tanaman, bobot tongkol kering panen per tanaman, panjang tongkol, diameter tongkol dan bobot 1.000 butir biji berkorelasi positif dengan hasil dengan katagori berbeda beda. Bobot tongkol kering panen, diameter tongkol dan bobot 1.000 butir biji tergolong kuat; tinggi tanaman dan jumlah daun tergolong sedang dan jumlah daun segar saat panen dan panjang tongkol tergolong lemah. Bobot brangkasan segar berkorelasi positif tergolong sedang dengan tinggi tanaman, jumlah daun total per tanaman, diameter batang dan jumlah daun segar saat panen per tanaman. Sifat lain termasuk katagori lemah dan sangat lemah.

\section{Pembahasan}

Seleksi massa dengan indeks dasar pada tanaman jagung, telah dilakukan selama delapan siklus di lahan kering. Indeks dasar, diperoleh melalui perkalian bobot masingmasing sifat (tongkol kering panen dan brangkasan segar). Bobot diperoleh dari perbandingan relatif output setiap sifat; yang didasarkan atas perolehan masing-masing sifat per plot, dikalikan harga saat panen percobaan. Seleksi ini bertujuan untuk meningkatkan hasil dan brangkasan segar (sifat stay-green). Bobot tongkol kering panen, digunakan untuk memperbaiki hasil, sehingga tergolong seleksi tidk langsung; sedangkan brangkasan segar merupakan seleksi langsung. Dalam penelitian ini dikaji rata-rata respon seleksi per siklus dan rata-rata hasil dan brangkasan segar serta sifat lainnya.

\section{Respon Seleksi}

Respon seleksi merupakan selisih rerata populasi hasil seleksi dengan rerata populasi sebelum diseleksi. Hal ini terjadi karena adanya peningkatan frekuensi gen berkenan akibat dilakukan seleksi (Ujianto et al., 2020). Seleksi massa dengan indeks dasar yang telah dilakukan selama delapan siklus, telah dikaji di lahan kering dengan tekstur geluh. Sifat hasil dan bobot tongkol kering panen memiliki repon seleksi; berturut-turut sebesar $0.230 \mathrm{~kg} \mathrm{plot}^{-}$ ${ }^{1}(3.39 \%)$ dan $2.794 \mathrm{~g} \mathrm{tan}^{-1}(2.21 \%)$ (Tabel 1). Hal ini berarti setiap siklus seleksi terjadi peningkatan rata-rata masing-masing sifat tersebut. Peningkatan hasil terjadi akibat adanya korelasi positif tergolong kuat dengan bobot tongkol kering panen sebesar 0.74 (Tabel 5). Pemilihan tongkol yang lebih berat pada setiap siklus seleksi, menyebabkan peningkatan hasil. Oktarina (2016) juga memperoleh hal sama, bahwa bobot tongkol kering panen per tanaman berkorelasi positif nyata dengan hasil sebesar 0.74 dan sebesar 0.94 diperoleh oleh Kusnarta dan Sudika (2018). Korelasi positif antara hasil dengan bobot tongkol kering panen tanaman jagung, diperoleh pula oleh Abdalla et al. (2010).

Respon seleksi hasil dan bobot tongkol kering panen per tanaman; keduanya tergolong sedang. Hal ini disebabkan oleh adanya heritabilitas kedua sifat tersebut tergolong tinggi; berturut-turut $60.27 \%$ dan $59.01 \%$ (Tabel 2). Heritabilitas yang tinggi, menggambarkan kontribusi ragam genetik lebih tinggi dibanding ragam lingkungan, sehingga menyebabkan adanya respon seleksi. Hal sama diperoleh oleh Pratama (2018), bahwa hasil memiliki nilai heritabilitas tergolong tinggi sebesar $60.32 \%$. Nilai koefisien keragaman genetik kedua sifat tersebut tergolong sedang masing-masing sebesar $10.78 \%$ untuk bobot tongkol kering panen 
dan $10.47 \%$ untuk hasil. Besarnya nilai koefisien keragaman genetik ini mendukung pula adanya respon seleksi untuk kedua sifat tersebut. Syukur et al. (2012) mengatakan, bahwa koefisien keragaman genetik yang tinggi menunjukkan adanya keragaman genetik yang luas. Keragaman genetik yang luas memudahkan pemilihan genotip-genotip unggul sesuai dengan karakter yang diinginkan. Basuki (2005) menambahkan, bahwa sifat yang memiliki keragaman genetik tinggi, maka sifat tersebut akan memiliki respon seleksi yang cukup besar. Adanya respon seleksi secara tidak langsung hingga siklus ketujuh untuk hasil sebesar $72.80 \mathrm{~g} \mathrm{plot}^{-1}$, juga diperoleh oleh oleh Sudika et al., (2018a). Sifat-sifat lain yang memiliki respon seleksi, yaitu tinggi tanaman, jumlah daun total, jumlah dun segar saat panen, panjang tongkol, diameter tongkol, bobot 1.000 butir biji dengan katagori rendah (Tabel 1) adalah merupakan seleksi ikutan. Seleksi ikutan terjadi akibat adanya korelasi genetik antar sifat yang diseleksi dengan sifat lain yang tidak diseleksi (Ujianto et al., 2020). Diameter batang merupakan sifat yang tidak memiliki respon seleksi kemungkinan akibat hubungan genetiknya dengan sifat yang diseleksi tidak ada.

Bobot brangkasan segar memiliki respon seleksi sebesar $10.633 \mathrm{~g} \mathrm{tan}^{-1}$ atau sebesar $4.21 \%$, dengan katagori tergolong sedang (Tabel 1). Sifat tersebut memiliki nilai heritabilitas tergolong sedang, sebesar $26.61 \%$ dan koefisien keragaman genetik tergolong sedang sebesar $9.54 \%$ (Tabel 2). Kedua nilai tersebut memberikan kontribusi pula untuk terjadinya respon seleksi. Penyebab lain adanya respon seleksi pada sifat ini tergolong sedang, kemungkinan akibat seleksi secara langsung. Dalam setiap siklus seleksi, bobot brangkasan segar digunakan sebagai kriteria seleksi; selain sifat bobot tongkol kering panen. Berdasarkan indeks seleksi kedua sifat tersebut, dapat ditentukan suatu tanaman terpilih atau tidak terpilih untuk setiap siklusnya.

\section{Perubahan Rata-rata Populasi}

Hasil (bobot biji kering pipil per plot) populasi hasil seleksi indeks siklus ke delapan (P8IS) lebih tinggi dibanding populasi awal (P0), varietas unggul Gumarang dan populasi hasil seleksi lainnya; namun sama dengan varietas unggul Lamuru. Hasil P8IS, P0, varietas Gumarang dan Lamuru, berturut-turut sebesar $9.64 \mathrm{~kg} \mathrm{plot}^{-1}$ (8.035 t ha-1); 6.78 (5.653); 6.33 (5.278) dan $8.89 \mathrm{~kg} \mathrm{plot}^{-1}$ (7.410 $\left.\mathrm{t} \mathrm{ha}^{-1}\right)$. Hasil populasi siklus ke delapan lebih tinggi dibanding dengan populasi awal, terjadi karena siklus seleksi telah dilakukan cukup banyak, yakni delapan siklus. Pada setiap siklus seleksi, dilakukan pemilihan tanaman untuk sifat yang diseleksi dan sifat yang diperbaiki. Tanaman yang terpilih memiliki genotip yang lebih baik dibanding tanmaan tidak terpilih. Hal ini berarti, kegiatan pemilihan tanaman setiap siklus, memberikan kontribusi pada peningkatan frekuensi gen dan frekuensi genotip. Peningkatan kedua frekuensi tersebut dapat diamati dari perubahan rata-rata populasi akibat seleksi. Hal ini sesuai pendapat Soemartono et al. (1992), bahwa seleksi menyebabkan perubahan frekuensi gen dan frekuensi genotip yang dapat dilihat dari perubahan rata-rata populasi. Dalam kegiatan seleksi massa dengan indeks dasar, hasil diperbaiki melalui bobot tongkol kering panen karena hubungan yang erat antar kedua sifat tersebut. Peningkatan frekuensi gen dan genotip pada bobot tongkol kering panen, juga menyebabkan peningkatan kedua frekuensi tersebut pada sifat hasil. Peningkatan hasil secara nyata, terlihat sejak siklus 
pertama. Peningkatan hasil secara nyata telah diperoleh pula oleh Sudika, et al. (2018b) hingga siklus kelima pada seleksi ini.

Rata-rata hasil populasi siklus ke delapan lebih tinggi dibanding populasi awal dan varietas unggul Gumarang, didukung oleh keempat komponen hasil yaitu panjang tongkol, diameter tongkol, bobot tongkol kering panen per tanaman dan bobot 1.000 biji. Pada Tabel 4 terlihat populasi siklus kedelapan memiliki tongkol lebih panjang dan diameter lebih besar dibanding populasi awal dan Gumarang. Ukuran tongkol lebih besar menyebabkan jumlah biji per tongkol lebih banyak, sehingga hasil lebih tinggi. Bobot 1.000 butir biji populasi tersebut juga lebih tinggi; berarti biji lebih bernas. Adanya jumlah biji lebih banyak dan lebih bernas, sehingga hasil populasi siklus delapan lebih tinggi dibanding populasi awal dan Gumarang. Hal ini didukung pula oleh nilai koefisien korelasi positif antara hasil dengan panjang tongkol, diameter tongkol, bobot tongkol kering panen per tanaman dan bobot 1.000 biji dan semuanya tergolong kuat. Hasil populasi siklus kedelapan sama dengan Lamuru karena keempat komponen hasil tersebut sama, seperti terlihat pada Tabel 4. Idris et al. (2011) memperoleh hal sama, bahwa panjang tongkol memperlihatkan korelasi positif nyata dengan berat biji kering pipil per tongkol (hasil).

Tanaman populasi siklus kedelapan lebih tinggi dan jumlah daun totalnya lebih banyak dibanding populasi awal. Hal ini juga mnyebabkan hasil lebih tinggi dibanding populasi awal. Populasi siklus kedelapan sama dengan varietas Lamuru karena kedua sifat tersebut sama. Kenyataan ini didukung oleh nilai koefisien korelasi kedua sifat dengan daya hasil bersifat positif nyata dengan katagori sedang dengan nilai berturut-turut 0.43 dan 0.45 (Tabel 5). Peningkatan tinggi tanaman dan bertambahnya jumlah daun total per tanaman menyebabkan hasil meningkat akibat lebih besarnya kapasitas fotosintesis. Hal ini didukung oleh penelitian Pratama (2018) dan Kusnarta \& Sudika (2018), bahwa jumlah daun berkorelasi positif nyata dengan hasil bertutut-turut sebesar 0.38 dan 0.39 .

Bobot brangkasan populasi siklus kedelapan sama dengan populasi awal, varietas Gumarang, Lamuru dan populasi siklus pertama hingga siklus ketujuh. Hal ini berarti, seleksi yang dilakukan selama delapan siklus belum mampu merubah secara nyata frekuensi gen dan frekuensi genotip sifat tersebut. Adanya respon seleksi yang tergolong sedang ini belum menyebabkan rata-rata populasi siklus kedelapan berbeda dengan populasi awal. Sifat-sifat yang merupakan penentu bobot brangkasan segar saat panen per tanaman, yaitu tinggi tanaman, jumlah daun segar saat panen dan diameter batang. Tinggi tanaman populasi siklus kedelapan lebih tinggi dibanding populasi awal; namun sama dengan populasi lain, varietas unggul Gumarang dan Lamuru. Jumlah daun segar per tanaman juga lebih banyak dibanding populasi awal hingga siklus kedua; sedangkan diameter batang sama untuk semua perlakuan. Penambahan tinggi tanaman secara nyata siklus pertama dan penambahan jumlah segar saat panen hingga siklus kedua, belum mampu menyebabkan penambahan secara nyata bobot brangkasan segar per tanaman. Nilai koefisien korelasi tinggi tanaman, jumlah daun segar dan diameter batang positif nyata dan tergolong sedang sebesar 0.57 ; 0.51 dan 0.54 . Keeratan hubungan tinggi tanaman dan jumlah daun segar, tidak mendukung untuk menyebabkan perbedaan populasi siklus delapan dengan populasi awal; namun keeratan diameter batang mendukung, sehingga bobot brangkasan segar per tanaman sama antar 
populasi awal dan varietas unggul Gumarang dan Lamuru. Hal sama diperoleh oleh Sudika et al. (2018b), bahwa hingga siklus kelima bobot brangkasan segar sama dengan populasi awal dan populasi siklus pertama hingga keempat dan varietas unggul Lamuru.

\section{KESIMPULAN}

Berdasarkan hasil analisis dan pembahasan yang telah dilakukan dapat diambil kesimpulan yaitu:

1. Hasil dan bobot brangkasan segar memiliki respon seleksi massa dengan teknik indeks dasar per siklus berturut-turut sebesar $0.230 \mathrm{~kg} \mathrm{plot}^{-1}$ dan $10.633 \mathrm{~g} \mathrm{tan}^{-1}$; keduanya tergolong sedang.

2. Rata-rata hasil populasi siklus kedelapan lebih tinggi dibanding dengan populasi awal dan varietas Gumarang; namun sama dengan varietas Lamuru. Hasil populasi awal, populasi siklus kedelapan, varietas Gumarang dan Lamuru berturut-turut sebesar $5.653 \mathrm{t} \mathrm{ha}^{-1}$; $8.035 \mathrm{t} \mathrm{ha}^{-1} ; 5.278 \mathrm{tha}^{-1}$ dan $7.410 \mathrm{t} \mathrm{ha}^{-1}$. Bobot brangkasan segar antar perlakuan sama.

3. Sifat yang pengaruh genetiknya lebih besar dibanding pengaruh lingkungan, diperoleh pada bobot tongkol kering panen per tanaman, panjang tongkol dan hasil.

4. Sifat bobot tongkol kering panen, hasil dan bobot brangkasan segar memiliki keragaman gentik tergolong sedang dan sifat lainnya tergolong rendah.

5. Korelasi yang kuat terjadi antara hasil dengan bobot tongkol kering panen per tanaman, panjang tongkol, diameter tongkol dan bobot 1.000 butir biji; sedangkan sifat lain tergolong lemah hingga sedang.

6. Seleksi indeks dasar masih dapat dilanjutkan pada siklus berikutnya untuk perbaikan hasil dan brangkasan segar; mengingat masih terdapat keragaman genetik untuk sifat yang diseleksi (bobot tongkol kering panen dan bobot brangkasan segar per tanaman) dan korelasi antar hasil dengan bobot tongkol kering panen tergolong kuat.

\section{UCAPAN TERIKA MASIH}

Penulis mengucapkan terima kasih yang sebesar-besarnya kepada Direktorat Jenderal Pendidikan Tinggi atas dana yang telah diberikan melalui Skim Penelitian Unggulan Perguruan Tinggi tahun 2019.

\section{DAFTAR PUSTAKA}

Abdalla A., Mahmoud M. F. and Naim A. M. E. 2010. Evaluation of Some Maize (Zea mays L.) Varieties in Different Enviromnents of the Nuba Mountain, Sudan. Australian Journal of Basic and Applied Sciences, 4 (12): 6605 - 6610.

Andriani, Suwarni W.B., Sutjahjo S.H. 2015. Pendugaan Keragaman Genetik dan Heritabilitas Jagung Hibrida Silang Puncak pada Perlakuan Cekaman kekeringan. Informatika Pertanian. 24: 91-100

Basuki, N. 2005. Genetika Kuantitatif. Fakultas Pertanian Universitas Brawijaya, Malang Budiyanto G. 2014. Pengelolaan Lahan Kering, Sebuah Model Pertanian Konservasi di Kawasan Hulu DAS Jratunsewna Jawa Tengah. RepositoryUMY. 1-22. 
Faiqon M.M., Supriyanta, Wulandari R.A. 2017. Pendugaan Parameter Genetik Komponen Hasil Untuk Seleksi Tidak Langsung Tanaman Padi (Oryza Sativa L.) Berdaya Hail Tinggi. Vegetalika. 6 (2): 14-24.

Helmiyanti W., Idris, Yakop U.M. 2012. Kemajuan Seleksi Indeks Terhadap hasil dan Berangkasan Segar pada Tanaman Jagung (Zea mays L.) di Lahan Kering Kabupaten Lombok Utara. Crop Agro. 2: 56-61.

Idris, Yakop U.M., Farida N. 2011. Kemajuan Seleksi Massa Pada Jagung Kultivar Lokal Kebo Setelah Satu Siklus Seleksi dalam Pertanaman Tumpangsari dengan Kacang Tanah. Crops Agro. 5: 37-42.

Istianingrum P., Damanhuri. 2016. Keragaman dan Heritabilitas Sembilan Genotip Tomat (Lycopersicum escilentum Mill.) pada budidaya Organik. Jurnal Agroekotek. 2: 70-81. Karmana M.H., Amalia L., Setiamihardja R., Permadi A.H. 1990. Pewarisan Heritabilitas dan Kemajuan Genetik Ketahanan Tanaman Cabai Merah Terhadap Penyakit Antraknosa. Zuriat 5 (1): 68-74.

Kusnarta I .G. M., Sudika I.W. 2018. Pengujian Daya Hasil Beberapa Varietas Tanaman Jagung pada Kondisi Cekaman Kekeringan yang Diberi Pupuk Kandang di Lahan Kering Lombok Utara. Jurnal Sains Teknologi \& Lingkungan. Vol. 4 (1): 43-53.

Litle, T.M. And F. J. Hills, 1972. Statistical Methods in Agricultural Research. Univ of California, Davis, California. $241 \mathrm{p}$

Oktarina N. 2016. Korelasi Genetik Pertumbuhan dan Hasil 15 Jagung Hibrida. [Skripsi, Unpublished]. Program Studi Agroekoteknologi, Jurusan Budidaya Pertanian, Fakultas Pertanian, Universitas Bengkulu. Bengkulu, Indonesia.

Pratama Y.M. 2018. Kajian Kemajuan Seleksi Indeks Siklus Ketujuh Pada Tanaman Jagung di Lahan Kering. [Skripsi, unpublished]. Budidaya Pertanian, Fakultas Pertanian, Universitas Mataram. Mataram, Indonesia.

Soemartono, Nasrullah dan Hari Hartiko, 1992. Genetika Kuantitatif dan Bioteknologi Tanaman. PAU Bioteknologi, UGM, Yogyakarta. $371 \mathrm{~h}$.

Sofyan Y., L. Aulia R. dan H. Kurniawan , 2011. Regresi dan Korelasi dalam Genggaman Anda. Salemba Empat, Jakarta. $308 \mathrm{~h}$.

Somantri A., Muhidin S.A. 2006. Aplikasi Statistika Dalam Penelitian. CV Pustaka Setia. Bandung

Sudika, A. Parwata dan Soemeinaboedhy. 2018a. Respon Seleksi Massa Secara Tidak Langsung Terhadap Daya Hasil Tanaman Jagung Selama Tujuh Siklus di Lahan kering. Jurnal Sains Teknologi \& Lingkungan. Vol. 4 (2): 144-152.

Sudika, A. Parwata dan Soemeinaboedhy. 2018b. Kajian Dua Teknik Seleksi Massa Guna Perbaikan Daya Hasil dan Stay-Green pada Tanaman Jagung di Lahan Kering. Prosiding Seminar Nasional Fakultas Pertanian Universitas Muhammadyah Mataram. p. $100-106$.

Sudika, Soemeinaboedhy.dan A. Parwata. 2019. Seleksi massa guna memperoleh varietas unggul jagung tahan kering, umur panen super genjah, Hasil dan brangkasan segar tinggi. Laporan Hasil Penelitian Tahun ketiga (Unpublish). 74 h. 
Syukur M., Sujiprihati S., Yunianti R. 2012. Teknik Pemuliaan Tanaman. Penebar Swadaya. Depok.

Wedastara M. S. 2011. Pemberdayaan Potensi Pertanian Lahan Kering Berbasis Agribisnis di Kabupaten Lombok Barat. Ganeç Swara. 5: 10.

Ujianto L., Muliarta A., Sudika, I W. dan Sudarmawan, A.A. 2020. Teknik Analisis dan Rancangan Persilangan. Mataram University Press, Mataram. $96 \mathrm{~h}$. 